\title{
SOVEREIGNTY ISSUES IN THE CAUCASUS: CONTESTED ETHNIC AND NATIONAL IDENTITIES IN CHECHNYA, ABKHAZIA, AND SOUTH OSSETIA
}

\begin{abstract}
The issue of sovereignty has been at the forefront of regional politics in the Caucasus since the dissolution of the USSR in 1991. In particular, the Russian government has approached various-seemingly similar cases-in very different ways. Although each specific region examined-Chechnya, Abkhazia, and South Ossetia-is unique, the nature of ethnic and national identity has been framed differently by the Russian government. In Chechnya, the Putin administration has framed any outstanding separatist claims in conjunction with terrorism and national security issues. In Abkhazia and South Ossetia, the Putin administration has instead noted the need for "liberation." The outcome has been to stifle secessionist desires in Chechnya, while supporting those same secessionist desires outside of Russia's borders, in Abkhazia and South Ossetia.
\end{abstract}

Key words: Chechnya; Abkhazia; South Ossetia; secession; terrorism

VASILI RUKHADZE Kent State University, Kent, United States E-mail: vrukhadz@kent.edu

KWESTIA SUWERENNOŚCI NA KAUKAZIE: KONTESTOWANE TOŻSAMOŚCI ETNICZNE I NARODOWE W CZECZENII, ABCHAZJI I OSETII POLUDNIOWEJ

GLEN DUERR Cedarville University, Cedarville, United States E-mail: gduerr@cedarville.edu

This work was supported

Streszczenie by the authors' own resources. No competing interests have been declared.

Kwestia suwerenności wysunęła się na czołowe miejsce Both authors participated in elaborating w polityce regionalnej na Kaukazie z chwilą rozpadu Związku research ideas and writing the manuscript.

This is an Open Access article distributed under the terms of the Creative Commons Attribution 3.0 PL License (creativecommons.org/licenses/by/3.0/pl/), which permits redistribution, commercial and non-commercial, provided that the article is properly cited. () The Author(s) 2016.

Publisher: Institute of Slavic Studies, Polish Academy of Sciences [Wydawca: Instytut Slawistyki PAN] 
Sowieckiego w 1991 roku. W istocie rząd rosyjski do poszczególnych, pozornie podobnych, przypadków podszedł w odmienny sposób. Aczkolwiek każdy z interesujących nas tutaj regionów - Czeczenia, Abchazja i Osetia Południowa - jest unikatowy, to charakter tożsamości etnicznej i narodowej został ujęty przez rząd rosyjski w inne ramy. W Czeczenii administracja Putina wiązała wysuwane tam roszczenia separatystyczne z terroryzmem i kwestiami bezpieczeństwa narodowego. Z kolei w Abchazji i Osetii Południowej Rosja dostrzegła potrzebę „wyzwolenia”. W efekcie nastąpiło stłumienie aspiracji do secesji w Czeczenii, podczas gdy poza granicami Rosji, w Abchazji i Osetii Południowej, te same dążenia secesjonistyczne zyskały sobie poparcie.

Stowa kluczowe: Czeczenia; Abchazja; Osetia Południowa; secesja; terroryzm

\section{INTRODUCTION}

T he first decade of the $21^{\text {st }}$ century was a significantly tumultuous period of time in the post-Soviet space. Despite the international norm that borders cannot change, instituted at the founding of the United Nations in 1945, and then reaffirmed by countries across Eurasia with the Helsinki Accords of 1975, borders have recently shifted in the region. In 2014, Russia annexed Crimea from Ukraine, and has also engaged in overt and covert operations in the Donbas region of eastern Ukraine, specifically in the Donetsk and Luhansk regions. The focus of this chapter, however, is on Russia's actions at the beginning of the century in Chechnya (in Russia's North Caucasus), as well in Abkhazia and South Ossetia (Georgia). Specifically, the focus is on the Second Chechen war that was initiated in 1999, and the conflict over Abkhazia and South Ossetia in 2008, because both of these conflicts served to solidify/change the borders of these countries.

The issue of sovereignty has been at the forefront of regional politics in the Caucasus since the dissolution of the Soviet Union in 1991, especially given the increased attention to ethnicity in the region. During the Soviet era, ethnicity was marginalized in favor of creating the idealized Soviet "Communist" man who shunned other factors of identity in favor of being part of the larger, non-ethnic based union. This trend is exemplified by the rise of "frozen conflicts" in the Post-Soviet region since 1991 based largely around the issue of ethnicity (Kaufman, 2001).

Since then, Russia has gone through a significant cultural transformation, which is reflected in the contestation of ethnic and national identities in the Caucasus. Distinct ethnic and national identities, in conjunction with a range of economic, political, and social factors heightened the contestation of the state through increased secessionist demands. Secessionism was pervasive in Russia in the early 1990s with numerous republics asserting demands from the central government (Giuliano, 2006). The Yeltsin administration largely dissuaded most of these secessionist groups through payments and/ or coercion, but some contestation remains, especially in the Caucasus. Interestingly, the Russian government has approached various-seemingly similar cases-in very different ways. Although each specific region examined-Chechnya, Abkhazia, and South Ossetia-is unique, the nature of ethnic and national identity has been framed differently by the Russian government, in pursuit of its own political goals.

Two primary questions arise in the backdrop of this situation: How did the Russian government frame secessionism in Abkhazia, South Ossetia, and Chechnya? And, why did the actions of the Russian government diverge across these three cases of seces- 
sionism? Answers to these questions will help to uncover how ethnicity has been more greatly politicized in the post-Soviet era, as well as how Russia acts (and also frames its actions) towards its neighbors.

In this chapter, the data show how the Russian government has dealt with each region differently. In Chechnya, a republic of Russia with longstanding secessionist movement, the Putin administration has framed any outstanding separatist claims in conjunction with terrorism and religious and national extremism. In essence, any secessionist overtures have been framed in light of terrorism (Pokalova, 2010; Campana \& Légaré, 2010). In Abkhazia and South Ossetia, territories within the Republic of Georgia with their own secessionist demands (Kaufman, 2001), the Putin administration has instead promoted the image of freedom loving national groups fighting against Georgian aggression, regardless of methodic ethnic cleansing of Georgians by Russian-backed local militias. The goal was to stifle secessionist desires in Chechnya, while supporting those same secessionist desires outside of Russia's borders, in the Georgian breakaway regions of Abkhazia and South Ossetia.

Utilizing discourse analysis, international news sources were examined with Lexis/Nexis in order to track the usage of certain phrases by the Putin administration to distinguish between their approaches towards Chechnya and Abkhazia/South Ossetia. We retrieved news articles from August 24, 1999 to September 24, 1999 (the first month of the Russian military campaign against secessionist Chechnya, including against Chechnya's incursion into neighboring Dagestan) and from August 8, 2008 to September 8, 2008 (one month that covers the Russian five day military invasion of Georgia and its immediate aftermath). These time periods were deliberately chosen during intense military hostilities. Investigating these cases during the heights of military conflicts best highlight official discourses in general and the Russian official discourses in particular.

Articles were chosen from a Russian source as well as a Western/American source as a means of control. This distinction allows for a basis of comparison between what is reported in Russia, and what is reported in the West. For Chechnya, The Moscow Times was chosen as the Russian source, and The New York Times as the Western/American source. For Abkhazia/South Ossetia, RIA Novosti was chosen as the Russian source, and The New York Times was once again selected as the Western/American source. These sources were chosen because they served as the most prominent symbol of Russian and Western journalism during the time periods of conflict-1999 and 2008.

All articles were uploaded into NVivo 10 and coded to show the distinctions in framing secessionism in Chechnya as different from Abkhazia and South Ossetia. Articles were then separated into four categories, and based on the framing created by the Russian government-specifically, high level members of the Putin and Medvedev cabinets. For the Chechnya conflict, articles were divided into discussions of a positive portrayal of the Russian government's actions in the region, and also of the negative actions of the Chechen separatists. We found 42 news articles from The Moscow Times, and 48 news articles from The New York Times on the Chechnya conflict. Four statements from The Moscow Times, and four statements from The New York Times noted positive framing by the Russian government; whereas, 14 statements were found in The Moscow Times and five statements were found in The New York Times outlining the negative actions of Chechen separatists. Overall, in these articles, on every occasion when the Russian government mentioned the conflict in Chechnya the coverage of separatists was negative in all (or on every single instance) cases, and the coverage of Russian government's actions 
was positive also in all (or on every single instance) cases. For Abkhazia and South Ossetia, articles were divided into discussions of positive actions of the Russian government in Georgia, as well as the negative actions of the Georgian government in Abkhazia and South Ossetia. Overall, 23 news articles from RIA Novosti were found during the time period, and 36 news articles from The New York Times on the Abkhazia/South Ossetia conflict. Thirteen statements from RIA Novosti, and one statement from The New York Times noted positive framing by the Russian government; whereas, 14 statements were found in RIA Novosti and three statements were found in The New York Times outlining the negative actions of Georgian government. In other words, in these articles too, the Russian government was overwhelmingly tendentious. On every occasion when the Russian authorities mentioned the conflicts in South Ossetia and Abkhazia, they framed the actions of the separatists and the Russian government in positive light in all (or on every single instance) cases, and the actions of the Georgian side in negative light in all (or on every single instance) cases.

The sample could have been much larger. However, the key goal was not simply to provide a high number of articles, but to capture the general picture of framing three secessionist movements in those three regions by the Russian government. In this regard, those four main sources and peer reviewed news updates, articles, and statements are fully representative of the framing trend that the Russian regime constructed. Enlarging the sample by including more sources (news updates, articles, and statements) would not change the picture by any means and would unnecessarily and unwisely increase the size of the text.

This study can contribute to the political science literature in showing how contested ethnic and national identities have been framed, resulting in very different outcomes for people living within the Caucasus region. This study can also contribute to the international relations literature by showing how resurgent Russian power has led to the decline of internationally accepted norms, such as state sovereignty and human rights, in the region.

\section{BRIEF REVIEW OF THE LITERATURE}

For this article, the literatures on nationalism, and the inter-related fields of secession and irredentism, are important to briefly review in order to establish the scholarly context of a comparison between cases. Definitions, in particular, are important because Russia's actions in the Caucasus region are based on numerous factors, which have, in all cases, led to issues of sovereignty and war in the region. Given the issues of sovereignty and war, a quick survey of these topics is useful to set the context of the discussion.

Nationalism is a field that was first, in large measure, developed and studied in the late $19^{\text {th }}$ and early $20^{\text {th }}$ centuries. It was popularized with an investigation of nationalism in Western Europe and contrasted visions of French and German nationalism in the aftermath of the Franco-Prussian War (Renan, 1882/1990). From this starting point, the field grew in scope and stature with numerous volumes examining the nature of nationalism, its origins, and its spread; in particular, the field grew immensely in the 1980s through to the present (see Anderson, 1983; Breuilly, 1982; Smith, 1981, 1986; Hobsbawm, 1990; Gellner, 1983). At its core, the study of nationalism examines the factors that undergird why, at a maximalist extent, different countries go to war with others, or why factions 
within a country go to war; at a minimalist extent, why tensions increase between countries, or between factions within a single country.

Secessionism is most succinctly defined as the "formal withdrawal from an established, internationally recognized state by a constituent unit to create a new, sovereign state" (Bartkus, 1999, p. 3), or, similarly, "a demand for formal withdrawal from a central political authority by a member unit or units on the basis of a claim to independent sovereign status" (Wood, 1981, p. 110). Secession is viewed by political philosophers as an event that should be generally discouraged, but one that should be able to happen (Buchanan, 1991; Moore, 2002). Secessionism is a global phenomenon and tends to impact heterogeneous countries. Demands for secession can be peaceful, as evidenced by the September 2014 referendum in Scotland, or the historic referendums in Quebec in 1995 and 1980. Peaceful secessionist movements try to attain their goals through the ballot box, rather than via violence. However, in contrast, secessionist movements often wage violent campaigns for independence, especially when they perceive the national government to be infringing upon their rights and liberties. One some occasions, autonomy is granted, but on other occasions, conflict starts. In this chapter, in particular, the issue of violent secessionism is examined. Secession is a rare phenomenon in world politics, and is particularly difficult in developed, democratic countries (Dion, 1996). Only three countries—South Sudan, Montenegro, and East Timor-for example, have gained their independence so far this century.

The situation in the Caucasus is more complex since there is an added possibility of irredentism, which is quite similar to the idea of secession. Irredentism is important to study because Russia's ambitions in its near neighborhood reflect irredentist ideas. Irredentism can be defined as "assume a more general usage concerning demands by any ethnic group for acquisition of territory claimed to be part of a historic homeland or populated by ethnic kin" (Nolan, 2002). Since both Russia and Ukraine were two of the fifteen republics of the Soviet Union, they share a history. Moreover, since ethnic Russians were very powerful during the Soviet era, and often moved to take positions of prominence across the country, large ethnic Russian populations exist in Ukraine, as well as Estonia, Latvia, and Kazakhstan, among other republics. The dissolution of the Soviet Union in 1991, highlighted by the revival of ethnicity in the 1980s, led to the increased importance of this variable, which had been subverted during the life of the Soviet Union. Given Russia's relatively weak position in the early and mid-1990s, Moscow did not engage in conflict. However, as stability returned to Russia, and oil revenues began to fill the state coffers, secessionism and irredentism became indelible features in the national debate on the growing insurrection in Chechnya in 1999.

\section{SOUTH OSSETIAN, ABKHAZ, AND CHECHEN SEPARATIST MOVEMENTS}

Separatist movements in Georgia's South Ossetia and Abkhazia regions and Russia's Chechen Republic have deep roots, stretching back into history. However, it is beyond the scope of this chapter to analyze all of the myriad causes, in addition to the historical evolution of those conflicts. Here, the focus is solely on the post-Soviet period of these separatist conflicts, emphasizing those aspects which are relevant to the key argument of this chapter. 
Among these three separatist conflicts South Ossetian and Abkhazian separatist conflicts in Georgia were the first ones to emerge, largely at the same time. As the crisisridden Soviet Union began to crumble at the end of 1980s when Gorbachev implemented a range of reforms in the state, Georgia, among other Soviet republics, began its plight to regain national independence; starting in 1986 with ethnic protests in Kazakhstan, and then spreading to the Baltics, thousands of people protested for independence (Beissinger, 2002). From this starting point, the spark emerged in the west of the Soviet Union, in the Baltics and Georgia. Initially, thousands of people began protesting for national sovereignty. When the Soviet Union, under Gorbachev, did not react as they had in Hungary in 1956 and Czechoslovakia in 1968 - with tanks in the streets - greater numbers of people protested on the streets for independence. By 1989, millions of people were protesting for independence each month (Beissinger, 2002).

In response, the Soviet regime did entangle itself in some areas. In particular, the Soviet government quickly instigated the ethnic-separatist conflicts within Georgia in order to destabilize the country, fragment it, and thus ensure its continued obedience to Moscow. Although the strategy was not repeated widespread, it did serve to initiate division in Georgia. (The Soviets pursued a similar strategy in Moldova wherein the predominantly pro-Russian Trans-Dniester region became a de facto independent entity from Chisinau, and remains in this situation today (Kaufman, 2001).

In 1989, violent ethnic clashes began between Ossetians and Georgians in South Ossetian Autonomous Okrug (region), populated by over 100,000 people, 66 percent of which were Ossetians and 29 percent Georgians. It quickly escalated, in September 1990 culminating into the creation of Democratic Soviet Republic of South Ossetia, separate from Georgia. In response, in December 1990, newly elected Georgian parliament (Supreme Soviet) abolished South Ossetian autonomy altogether (Zürcher, 2005, pp. 90-92). This point in history was particularly complex given that the Soviet Union began to dissolve in 1991. First, the Baltic States declared their independence-and were recognized by several states throughout the world. Second, the Belavezah and Almaty Accords were initiated on December 8 and 21 respectively, which served to dissolve the Soviet Union into 15 independent republics. (Only republics gained independence; all lower level subnational units, like Chechnya, were grandfathered in to the newly independent Russia.)

In the midst of these changes, and in the aftermath of the Georgian parliament's action was the start of a low intensity war in 1991-1992, during which Russian military continuously supplied Ossetian separatists with weapons. Gradually, Georgian forces lost control over the South Ossetia's capital Tskhinvali, adjacent Java district, and a range of villages in the conflict zone. Overall, the war claimed the lives of about one thousand people and forced over 20,000 Georgians to flee their homes and the region. The war formally ended on June 24, 1992, by Dagomys (Russian Federation) ceasefire agreement, signed between Georgia and Russia. ${ }^{1}$

By the Dagomys agreement then Georgian President Eduard Shevardnadze, in fact, capitulated to Russia. The treaty established Joint Control Commission (JCC) to supervise the conflict zone. JCC consisted of four members: Georgia, Russia, South Ossetia, and North Ossetia, thus leaving Georgia alone against the three hostile parties. Even more so, Dagomys agreement established 2,000 men strong Joint Peacekeeping Force (JPKF), which reinforced Georgian isolation. JPKF consisted of only 500 Georgian sol-

1 Periodic armed clashes between Ossetians and Georgians, however, became regular occurrence in the following years. 
diers. The other 1,500 soldiers were evenly split between Russia, South and North Ossetia. Overall, by the JCC and JPKF Russia created the mechanisms by which it could effectively block any political move by Georgia, aimed at conflict resolution or change of the peacekeeping format. ${ }^{2}$

This is exactly what Russia persistently did since 1992, halting all Georgian efforts to launch direct dialogue with Ossetians and solve the conflict. Since 2000, the new administration of President Vladimir Putin in Russia saw the South Ossetian conflict as a useful means to further destabilize Georgia and undermine its pro-western foreign policy course, since Georgia sought to achieve ultimate membership into North Atlantic Treaty Organization (NATO) and European Union (EU). The borders of both NATO and the EU expanded outwards to Russia in 2004 when the Baltic States gained entrance into these organizations. President Bush of the United States then advocated accession for both Ukraine and Georgia. In the backdrop of these events, tensions in the conflict zone grew, culminating into the armed clashes in August 2004, which claimed dozens of lives (International Crisis Group, 2007, p. 1).

Tensions remained high ever since, accompanied by occasional violence. President Putin's administration provided active political and military backing to South Ossetian separatist regime and tried, and successfully so, to undermine new Georgian President Mikhail Saakashvili's all efforts to reach out to Ossetians and solve the conflict or at least change the peacekeeping format (Asmus, 2010, pp. 53-109). One of those subversive tactics of the Putin administration was granting of Russian citizenship to Ossetians en masse, in blatant violation of the Georgian sovereignty, in order to gain a pretext for the military intervention in Georgia under the slogan of defending Russian citizens (thus Ossetians) from alleged Georgian "aggression" (Artman, 2014). This was the overall situation in South Ossetia before the outbreak of the August 2008 Russian-Georgian war.

By the end of July and beginning of August violent armed clashes intensified, which was followed by massive Russian military intervention on August 8, in what became known as the 2008 Russian-Georgian War. Russia blamed Georgia for starting the war and accused it of attacking Russian peacekeepers, as well as the city of Tskhinvali. ${ }^{3}$

After several days of intense fighting, invading Russian Army, further backed by Ossetian and Chechen militias, overwhelmed the Georgian army. Russians evicted Georgian forces from entire South Ossetia, thus Akhalgori district and dozens of villages in the conflict zone which were still controlled by the Georgian side. Moreover, Russians briefly occupied the city of Gori, outside of South Ossetia. Russian invasion was accompanied by massive ethnic cleansing of Georgians by Ossetian and Chechen militias, which forced tens of thousands of Georgians from their homes. After the August 12 ceasefire agreement, brokered by the EU, Russians and militias left Gori. However, Russia maintained strong military presence in South Ossetia and on August 26, 2008, recognized its independence, along with that of Abkhazia, discussed below (Asmus, 2010, pp. 165-214).

Abkhazia was another Georgian region where Moscow skillfully stirred ethnic-separatist tensions among Abkhazs against Georgians since the mid-1950s. In the late 1980s, when Georgia intensified its struggle to break away from the Soviet Union,

\section{......}

2 In his 2006 interview with Radio Free Europe/Radio Liberty (RFE/RL), then ex-president Eduard Shevardnadze in fact, acknowledged that he capitulated by this agreement. However, he justified his action by the immediate need to stop the war ("Georgia: Shevardnadze discusses 1992 South Ossetia agreement", 2006).

3 The EU-sponsored report that was drafted by the Independent International Fact-Finding Mission on the Conflict in Georgia (so called Tagliavini report, named after the mission's chairperson Swiss diplomat Heidi Tagliavini), in fact, blamed Georgia for starting the war, but accused Russia of provoking the war. For the link to the report see: "Independent international fact-finding mission on the conflict in Georgia" (2009). 
these tensions turned into violent clashes between Abkhazs and Georgians (Daushvili, 2008, pp. 469-475).

In 1991, Georgia's first democratically elected national government, led by independent Georgia's first President Zviad Gamsakhurdia, struck a power sharing deal with Abkhazs. The deal granted ethnic Abkhazs, containing just 17.8 percent (about 80,000 people) of Abkhazia's total population, 28 seats (about 43 percent) in 65-seat legislature (Zürcher, 2005, p. 95). ${ }^{4}$

In January 1992, Gamsakhurdia was overthrown in a military coup. Abkhaz militias took advantage of ensuing civil war between the Gamsakhurdia's supporters and the new regime, led by the former Soviet Foreign Minister Eduard Shevardnadze and attacked government buildings in June 1992. In July 1992, the separatist regime declared independence from Georgia. In response, rag tag Georgian military units entered Abkhazia and quickly captured most of the region, including capital Sukhumi. Separatists held on Gudauta and Tkvarcheli districts. ${ }^{5}$ Thus the War of Abkhazia began.

Military conflict lasted for 15 months, from August 1992 to September 1993. Russia played the key role in the war, firmly siding with the separatists. Thousands of volunteers from southern Russia (Russian Cossacks) and Russia's North Caucasus republics fought on the Abkhaz side. Among them was Chechen commander Shamil Basayev, whom Moscow later declared number one Chechen terrorist. Moreover, Russia provided crucial help to separatists with military hardware: tanks, artillery, aviation, navy, and all the necessary ammunition. ${ }^{6}$

Gradually, Russian-backed separatists turned the tight of the war. In October 1992, they captured the highly important city of Gagra and in September 1993, the capital Sukhumi, followed by the rapid fall of Ochamchire and Gali. Georgian forces were comprehensively defeated and thus ejected from Abkhazia, with the exception of narrow Kodori Gorge, in the northeast of the region. Abkhazs followed up their victory by widespread ethnic cleansing, which forced about 250,000 Georgians to flee Abkhazia and move across river Enguri into other parts of Georgia. The war devastated the region, as well as Georgia's entire economy and claimed the lives of about 8,000 thousand Abkhazs and 30,000 Georgians. ${ }^{7}$

Russia achieved its goal of maintaining control over Georgia. Specifically, the Georgian government, defeated in the war, agreed to become a member of Russian-dominated Commonwealth of Independent States (CIS), set up in the aftermath of the dissolution of the Soviet Union, and entered into negotiations with Moscow over the future of Russian military bases in Georgia (Zürcher, 2005, pp. 96-97). Moreover, Moscow imposed on Georgia a peacekeeping format, which in fact, entrenched Russian military, as well as political influence in Abkhazia and effectively froze the conflict. Specifically, CIS peacekeeping force, in fact, Russian military contingent, was deployed on both sides of Abkhazia's administrative border with the rest of Georgia (De Waal, 2010, p. 164). United Nations mission (the United Nations Mission in Georgia or UNOMIG) was established in August

4 The agreement, however, began to breakdown already in early 1992

The Georgian government claimed that its forces entered Abkhazia in order to protect Abkhazia section of the Georgian-Russian railway from Gamsakhurdia's supporter military forces and release some Georgian government officials, captured by pro-Gamsakhurdia militias.

6 The authors' interviews with 17 Georgian veterans of Abkhazia war (November 10, 2012-February 20, 2013).

7 Precise number of Georgian casualties always was a subject of debate in Georgia. Some put the figure at 33,000 , others as low as 15,000. Most sources, however, agree that about 30,000 Georgians, civilians and military, died in the conflict. 
1993, which eventually provided about 140 unarmed monitors on the ground, ${ }^{8}$ but made no meaningful impact on the conflict resolution.

Vladimir Putin, after ascending to power, saw Abkhazia as another effective tool (along with South Ossetia) to destabilize and blackmail Georgia and undermine its prowestern foreign policy course. Gradually, Putin's administration lifted economic embargo on Abkhazia, granted Russian citizenship en masse to Abkhazs (using the same model that he used to amend citizenship in South Ossetia, discussed above), and tightened its military and political grip over the region. In the run up to the 2008 Russian-Georgian war Moscow rehabilitated Abkhazia railway and deployed 20,000 Russian troops in the region (Asmus, 2010, pp. 165-166).

When the war broke up, Russia quickly opened the second front from Abkhazia against Georgia. Russian forces, further aided by Abkhaz militia, crossed the administrative border and swiftly captured Georgian-held Kodori Gorge (in Abkhazia's northeastern part) and a range of cities in Georgia's Samegrelo region. Although after the ceasefire agreement Russian army withdrew from Samegrelo region, Georgia lost control over Kodori Gorge. In fact, by capturing Kodori, Russia completed the occupation of entire Abkhazia (Georgian Public Broadcaster-Channel 1 TV, August 8, 2008-September 15, 2008).

Another separatist conflict, but this time in Russia's North Caucasus republic of Chechnya, took different direction. In September-October 1991, Chechen nationalist leader Dzhokhar Dudayev, former Soviet Air Force General, captured power in Chechnya and became a president. The new regime pushed hard to break away from Russian Federation and establish independent state. In November 1991, Chechen leader Dudayev made an initial declaration of independence for the region; although, this was not supported by the international community, or recognized by Russia (Berman, 2013, p. 43).

In 1993, Chechen government declared Chechnya's full independence from Moscow, thus realizing the dream of national independence of many generations of Chechens since the 19th century. In total, the Chechen government agitated for independence in a number of ways including: declaring sovereignty, boycotting the 1991 Russian Federation presidency referendum, establishing a presidency, refusing to pay taxes to Moscow, refusing to sign President Yeltsin's 1992 Federation Treaty, adopting a separate constitution, elevating Chechen law over Russian law, boycotting the referendum on Yeltsin in April 1993, and boycotting the referendum on the new Russian Constitution in December 1993 (Giuliano, 2006, p. 283). For all of these reasons, animosity between Grozny and Moscow continued to grow.

Tensions and occasional clashes between Chechnya, on the one hand, and Russia and anti-Dudayev forces within Chechnya, on the other hand, turned into an all-out war in December 1994. Russian hopes of rapid victory were quickly dashed, as Chechen forces put up ferocious resistance against numerous, but demoralized and disorganized Russian invading troops, which mostly consisted of poorly trained new conscripts. However, Russian federal forces, due to the overwhelming firepower and manpower, finally captured capital Grozny in March 1995, after months of fighting and thousands of military and civilian casualties. Moreover, Russian Army gradually expanded controlled territory, first in the lowlands and then in the highlands of Chechnya. ${ }^{9}$

The war was accompanied by savage violence between the conflict sides. Russian federal forces conducted blanket aerial bombings and used heavy artillery against civi-

8 On UNOMIG' mission and mandate see, "United Nations Observer Mission in Georgia" (2015).

9 For a thorough account of the Chechen struggle for independence see Akhmadov and Lanskoy (2010). 
lian population, regularly resorted to torture, summary executions, looting, rape, and abductions for ransom, as well as for political retaliation. Moreover, the Russian government managed to block and restrict journalists from covering the events in Chechnya, so an exhausted list of atrocities committed is not fully known (Ignatieff, 2000, p. 196). In response, Chechen rebels took hostages on masse, kidnapped individuals for ransom, killed Chechen collaborators, and mutilated captured Russian soldiers.

Chechens continued fierce resistance, inflicting heavy casualties on Russian troops in a series of surprise attacks. In spring-summer 1996, Chechen forces launched another phase of attacks across Chechnya. As a result, they captured capital Grozny and surrounded Russian garrisons in some other key cities. In August 1996, Russia and Chechnya signed Khasav-Yurt agreement, which stopped fighting, assured the withdrawal of all Russian troops from Chechnya by the end of 1996, and in fact, gave Chechnya de facto independence from Russia. According the November 1996 Moscow Peace Treaty, Russia even agreed to pay reparations to Chechens affected by the war. ${ }^{10}$

The first Chechen War ended, bringing fragile peace in Chechnya. However, the human cost of the war was colossal. It claimed the lives of from 80,000 to 100,000 Chechens (both civilians and military) in about one million large Chechnya and displaced tens of thousands of more. Russian military casualties varied, by different estimates ranging from 5,000 to 14,000 dead. Moreover, the scale of destruction was appalling, as capital Grozny and large parts of Chechnya, and subsequently its economy, lay in ruins.

De-facto independent Chechnya's new government also faced new political problems. Specifically, Chechen warlords, which led radicalized Islamist militias of Chechen and nonChechen (mostly Arab) fighters, did not obey the government and often even fought it. They engaged in military incursions and kidnappings for ransom in Chechnya and across the rest of Russia's North Caucasus. Political violence and religious extremism, mainly manifested in the form of Islamist Wahhabism, spread.

One of the rogue Chechen warlords was Shamil Basayev, who along with another Islamist commander Ibn Al-Khattab, a Saudi of Chechen decent, launched a military incursion on neighboring North Caucasus Republic of Dagestan in August-September 1999. Basayev's Islamic International Brigade captured a number of border towns and villages. The military incursion was accompanied by a series of bombings in September. First bombing took place on September 4, in Dagestani city of Buynaksk. It destroyed the building for Russian servicemen, killing 62 people. Within next two weeks a series of bombings in Russia's capital Moscow and the city of Volgodonsk targeted a mall and destroyed apartment complexes, killing about 280 people (Gordon, 1999).

The Chechen side denied any involvement, while Moscow quickly blamed Chechens for these bombings. Some Russians, however, argued that it was actually Russian Federal Security Service (Russian acronym FSB) which masterminded the bombings on the orders of the serving Prime Minister Vladimir Putin, in order to find a pretext for the Russian invasion of Chechnya and also to help Putin's ascension to presidency, as President Boris Yeltsin was planning to transfer power to him, ahead of the March 2000 presidential elections. ${ }^{11}$

\section{-....}

10 In May 1997, Chechnya and Russia signed a formal peace treaty in Moscow, which supposedly should cement peace between the two sides. As future developments showed, the treaty did not last for long.

11 On this topic see Satter (2004). 
In any case, the bombings and subsequent spread of mass fear in Russian public, certainly helped Putin to launch Second Chechen War. On August 24, 1999, Russian air forces began bombarding Chechnya and also gradually pushed back Chechens out of the neighboring republic, Dagestan in coordinated ground and air operations. On October 1, federal forces began the land invasion of Chechnya (Sakwa, 2005, pp. 1-42).

\section{ANALYSIS}

After an investigation of statements made by the Putin administration in the lead up to the wars in Russia's North Caucasus and Georgia, it is evident that similar cases were framed in very different ways. Separatists in Chechnya, as well as in South Ossetia and Abkhazia, all agitated for independence, but the Russian government reacted very differently.

On the issue of Chechnya, the Russian government framed their actions as positive by linking the issue of separatism as terrorism, but also as a defense of national sovereignty. In The Moscow Times, Putin notes his desire to protect Russia from "bandits" and "terrorists." He also noted that "Russia is defending itself." Similar stories are noted in The New York Times wherein these same themes are repeated by Putin. For example, as Prime Minister Putin notes, the government's "main objective...[is] protecting our (Russia's) citizens against terrorism and protecting our country's (Russia's) integrity."

The Russian government also framed the actions of Chechnya's separatists in a very negative light, despite an inability to win the "hearts and minds" of the people (see Younkyoo \& Lee, 2013). In The Moscow Times, Chechen separatists were framed as "militants," "bandits," "rabid animals," "vermin," "criminals," "Islamist terrorists," and "international saboteurs." To be sure, members of the Chechen forces committed atrocities and acts that would fall under a definition of terrorism, but the framing of separatism in light of these issues should be taken in context with Abkhazia and South Ossetia. In The New York Times, similar themes were reported as the Putin administration. However, there were significantly fewer statements discussing the actions of Chechen separatists, and, when listed, these were typically quotes from members of the Putin administration.

In The New York Times, similar themes were reported as those listed in The Moscow Times. The same themes were used by the western paper simply reported what was said by the Putin administration. However, by comparison to The Moscow Times, there were significantly fewer statements discussing the actions of Chechen separatists, and, when listed, these were typically quotes from members of the Putin administration.

On the issue of Abkhazia and South Ossetia, the Russian government framed itself in overwhelmingly positive light. In RIA Novosti, several statements portrayed the Russian military invasion as a noble and necessary effort to insure Abkhazian and South Ossetian "security." In The New York Times' and The Moscow Times' articles the Russian leadership portrays the Russian invasion of Georgia as "the operations to oblige Georgia, the Georgian authorities, to restore peace to South Ossetia." On another occasion, the Russian government positions Russia as a guarantor of security in Caucasus. Additionally, the Medvedev administration framed itself in a moral light noting the importance of international law, as well as the need to protect Russian (thus ethnic Ossetian and Abkhaz) citizens. 
In contrast, Georgians were framed as "war criminals" and "aggressors" in the context of horrendous atrocities inflicted by the Russian military and the government on Chechnya's population. In RIA Novosti, in particular, the Georgian government was lambasted by Russian officials over their conduct in Abkhazia and South Ossetia. The Medvedev administration continually noted the "aggression of Georgia" and the need to respond to this aggression with force. On eight occasions, RIA Novosti reported a Georgian attack, or Georgian aggression. Moreover, in The New York Times and RIA Novosti highest ranking Russian authorities accuse Georgians of committing "war crimes" and "ethnic cleansing" in South Ossetia, the very actions that Russian forces committed in Chechnya and then Russian-backed Ossetian and Chechen militias carried out against local Georgians in South Ossetia.

From this analysis, a clear pattern emerges. The Putin/Medvedev administrations framed secessionist conflict in Chechnya and Abkhazia/South Ossetia in very different ways (for further information on framing in Chechnya, see Campana \& Légaré, 2010). Chechen separatists were framed as "terrorists," "bandits," and "criminals," among other terms. In contrast, when Georgia responded to secessionism in Abkhazia and South Ossetia, the Medvedev administration framed it as aggression, and cited the need for Russia to intervene to protect the security of Russian (thus ethnic Ossetian and Abkhaz) citizens. In Chechnya and Abkhazia/South Ossetia, both Chechen separatists and Georgian military forces made mistakes, but the Russian government treated two similar circumstances in vastly different ways.

Although there are clearly differences between the cases such as ethnic background, economic situation, and governance structures, among others, there is still a significant divergence in the tactics used by the Russian government. The literature on secession tends to reserve independence for cases of significant grievance, even whilst upholding the principle of self-determination (Buchanan, 1991; Moore, 1998). This means that the respective secessionist leaders in Chechnya, Abkhazia, and South Ossetia will all be hard pressed to gain international support for their independence movements anyway, but secession is an option under specific circumstances; in reality, secession is mostly seen as legitimate only in the aftermath of conflict (Buchheit, 1978).

The puzzle this chapter has examined is this divergence between Chechnya and Abkhazia/South Ossetia. Why did the Russian government support independence in Abkhazia/South Ossetia whilst quashing self-determination in Chechnya? Differences are significant between these cases, but Russia's notion of imperialism is paramount in the wide divergence of cases. A more moderate approach might have been to increase the political powers of Chechnya within Russia, whilst simultaneously pressing the Georgian government to deliver similar opportunities in Abkhazia and South Ossetia. Although this plan has its limitations, and it is difficult to predict what would have happened if further devolution would have been granted-in some cases it pacifies secessionist movements, and in others cases it reifies them (Bird, Vaillancourt, \& Roy-Cesar, 2010) - it would have at least treated the cases more evenly. In short, there were many options that the Russian government could have used short of military action in a neighboring country, which, in many respects, set the situation for further actions in Ukraine in 2014. 
From this analysis, it is clear that Russia used very different arguments to confront similar cases. Obviously, the situation in Chechnya diverge in some ways from Abkhazia and South Ossetia, but, at the core, secessionist demands based on ethnic and historical factors drove the movements. Russia's response, however, was much more about national motivations and interests than a clear, consistent response.

Coding from Russian and Western/American sources shows that the Putin government linked secessionism with terrorism in overt ways in Chechnya. In contrast, the Medvedev government acted against the Georgian government when it sought to stop secessionism in Abkhazia and South Ossetia. Russia used military force to recognize the independence of these two regions. Despite very similar circumstances, the Russian government acted in two very different ways to suit what it views as its national interests. This action should be seen as a warning to the international community, and to countries wherein Russian citizens (or Russian-allied citizens) reside.

In some respects, it can be expected that Russia will continue to act in what it perceives to be its national interests. However, there are significant concerns for post-Soviet neighboring states that may suffer a loss of territory if Russia sees a rationale for engaging in a military attack. Some evidence of this can already be seen in Ukraine with the annexation of Crimea in March 2015, and their incorporation into Russia as the $84^{\text {th }}$ and $85^{\text {th }}$ federal subjects (Crimea is a republic, and Sevastopol is a federal city). The crisis in the Donbas region of Ukraine is not yet resolved, either, and could result in one of three outcomes. First, it could lead to a similar situation as the aforementioned "frozen conflict" like Trans-Dniester wherein the region has de facto independence, but has pledged allegiance to Moscow. Second, like Crimea, it could result in a formal annexation by Russia in future. Or, finally, the Abkhazia/South Ossetia model could be followed in that Moscow would support the "independence" of this region, granted that it occurs under Russian protection.

The major remaining question is what will happen to Russia as ethnicity continues to grow as a major factor. Will Russia seek to act in the interests of ethnic Russians (or ethnic groups closed allied with Russia) in the future? And, will Russia continue to use ethnic card for its expansionist foreign policy? If so, will the international community act to uphold the international norm that borders should not change. The cases of Chechnya, as well as Abkhazia and South Ossetia, provide some evidence that Russia will continue to act in its own national interests, which, in the Russian context, is akin to following an imperialist impulse. In doing so, separatists within Russia will be dealt with harshly, whilst ethnic Russian separatists outside Russia will be defended and hence, used to justify territorial expansion and dismemberment of neighboring countries. This, it seems, is the current policy of the Putin administration. The international community should expect-and also react-to this behavior. 
Akhmadov, I., \& Lanskoy, M. (2010). Chechen struggle: Independence won and lost. New York: Palgrave Macmillan. http://dx.doi.org/10.1057/9780230117518

Artman, V. (2014, March 14). Annexation by passport. Aljazeera. Retrieved 2 April 2016, from http://america.aljazeera.com/opinions/2014/3/ukraine-russia-crimeapassportization citizenship.html

Asmus, R. (2010). A little war that shook the world: Georgia, Russia, and the future of the West. New York: Palgrave Macmillan.

Bartkus, V. O. (1999). The dynamics of secession. Cambridge: Cambridge University Press. http://dx.doi.org/10.1017/CBO9780511491214

Beissinger, M. (2002). Nationalist mobilization and the collapse of the Soviet State. Cambridge: Cambridge University Press. http://dx.doi.org/10.1017/CBO9780511613593

Berman, I. (2013). Implosion: The end of Russia and what it means for America. Washington D.C.: Regnery Publishing.

Bird, R., Vaillancourt, F., \& Roy-Cesar, E. (2010). Is decentralization "glue" or "solvent" for national unity? Georgia State University. (International Working Paper series)

Buchanan, A. (1991). Secession: The morality of political divorce from Fort Sumter to Lithuania and Quebec. Boulder: Westview Press.

Buchheit, L. (1978). Secession: The legitimacy of self-determination. New Haven, CT: Yale University Press.

Campana, A., \& Légaré, K. (2010). Russia's counterterrorism operation in Chechnya: Institutional competition and issue frames. Studies in Conflict \& Terrorism, 34(1), 47-63. http://dx.doi.org/10.1080/1057610X.2011.531458

Civil Georgia. (2010). Georgia pulls out troops, hands over key positions in South Ossetia. Retrieved 2 April 2016, from http://civil.ge/eng/article.php?id=7666\&search

Daushvili, A. (2008). Rusuli kolonializmis tsinaaghmdeg brdzola XX saukunis meore nakhevarshi [The struggle against the Russian colonialism in the second half of the $20^{\text {th }}$ century]. In A. Bendianishvili, A. Daushvili, M. Samsonadze, K. Qoqrashvili, D. Chumburidze, \& O. Janelidze (Eds.), Rusuli kolonializmi saqartveloshi [Russian colonialism in Georgia] (pp. 449-485). Tbilisi: Universali.

De Waal, T. (2010). The Caucasus: An introduction. New York: Oxford University Press.

Dion, S. (1996). Why is secession difficult in well-established democracies?: Lessons from Quebec. British Journal of Political Science, 26(2), 269-283. http://dx.doi. org/10.1017/S0007123400000466

Georgia: Shevardnadze discusses 1992 South Ossetia agreement. (2006, February 23). RadioFreeEurope/RadioLiberty. Retrieved 9 May 2015, from http://www.rferl.org/content/article/1066081.html

Giuliano, E. (2006). Secessionists from the bottom up: Democratization, nationalism, and local accountability in the Russian transition. World Politics, 58(2), 276-310. http:// dx.doi.org/10.1353/wp.2006.0025

Gordon, M. (1999, September 18). Another bombing kills 18 in Russia. The New York Times. Retrieved 2 April 2016, from http://www.nytimes.com/1999/09/17/world/another -bombing-kills-18-in-russia.html

Ignatieff, M. (2000). Virtual war: Kosovo and beyond. Toronto: Viking Press. 
Independent international fact-finding mission on the conflict in Georgia. (2009, September). Retrieved 13 April 2015, from http://news.bbc.co.uk/2/shared/bsp/hi/pdfs/ 30_09_09_iiffmgc_report.pdf

International Crisis Group. (2007). Georgia's South Ossetia conflict: Make hassle slowly. Europe Report No 183 - 7 June 2007. Retrieved from http://www.crisisgroup.org/ / media/Files/europe/183_georgia_s_south_ossetia_conflict_make_haste_slowly.ashx

Kaufman, S. (2001). Modern hatreds: The symbolic politics of ethnic war. Ithaca, NY: Cornell University Press.

Litvinenko, A., \& Felshtinsky, Y. (2007). Blowing up Russia: The secret plot to bring back KGB terror. New York: Encounter Books.

Moore, M. (Ed.). (1998). National self-determination and secession. Oxford: Oxford University Press. http://dx.doi.org/10.1093/0198293844.001.0001

Nolan, C. (2002). The Greenwood encyclopedia of international relations. Westport, CT: Greenwood Publishers.

Pokalova, E. (2010). Framing separatism as terrorism: Lessons from Kosovo. Studies in Conflict \& Terrorism, 33(5), 429-447. http://dx.doi.org/10.1080/10576101003691564

Renan, E. (1990). What is a nation? Nation and Narration, (11), 8-22. (First published 1882)

Sakwa, R. (2005). Introduction: Why Chechnya? In R. Sakwa (Ed.), Chechnya: From past to future (pp. 1-20). London: Anthem Press.

Satter, D. (2004). Darkness at dawn: The rise of the Russian criminal state. New Haven: Yale University Press.

United Nations Observer Mission in Georgia. (2015). Retrieved 9 May 2015, from http:// www.un.org/en/peacekeeping/missions/past/unomig/index.html

Wood, J. (1981). Secession: A comparative analytical framework. Canadian Journal of Political Science, 14(1), 107-134. http://dx.doi.org/10.1017/S000842390003537X

Zürcher, C. (2005). Georgia's time of troubles, 1989-1993. In B. Coppieters \& R. Legvold (Eds.), Statehood and security: Georgia after the Rose Revolution (pp. 83-115). Cambridge, MA: MIT Press.

APPENDIX

\section{Chechnya-August 24, 1999-September 24, 1999.}

Russian actions in Chechnya portrayed in positive light by the Russian regime:

The Moscow Times (42 news entries)

1) Putin: we intend to protect our population from bandits and from foreign mercenaries.

2) Russian Colonel General Manilov: our main task [is] the liquidation of terrorist formations on the territory of Russia. 
3) Putin (on Chechen incursion in Dagestan): Russia is defending itself. We were attacked.

4) Putin: Now a fight is going on for the integrity of the Russian state.

The New York Times (48 news entries)

5) Putin about Chechen assault: [Russians] "have no right to fail in uniting around the main objective of protecting our citizens against terrorism and preserving our country's integrity."

6) Putin: "We will pursue the terrorists everywhere...You will forgive me, but if we catch them in the toilet, we will rub them out in the outhouse."

7) Putin on Chechen incursion: [Russia] "must brush away the syndrome of guilt developed in previous years," an obvious reference to the Chechnya debacle. "We have been attacked," he said, "and if no cardinal measures are taken, the bandits will manage to penetrate into a third district of Dagestan."

8) Putin: [we will] pursue the terrorists everywhere... if we catch them in the toilet, we will rub them out in the outhouse.

Chechen separatists in Dagestan and Chechnya portrayed in negative light by the Russian regime:

The Moscow Times (42 news entries)

1) Official Moscow says they will keep bombing militants (in Chechnya) until they destroy them all.

2) Putin: Bandits will be hit where they are. If they are at an airport then at an airport.

3) Putin: Muslim counties were supporting Chechen fighters.

4) Deputy Head of FSB Kozlov: Saudi Arabia and Pakistan are funding rebels.

5) Defense Ministry Spokesman: measures are being taken to prevent the infiltration of terrorist groups (into Dagestan from Chechnya).

6) Putin calls separatists (after apartment bombings): rabid animals. He says: "It is difficult even to call them animals. If they are animals, then they are rabid,"

7) Putin: Russia is under from terrorist forces.

8) Putin in the aftermath of the bombings within Russia: "we must act decisively - grit our teeth and crush the vermin at the root."

9) Russian police claims a bomb in apartments were planted by Islamic terrorists.

10) Putin calls separatists (those who, as he asserts participated in apartment bombings) criminals.

11) Putin calls international saboteurs those invaded Dagestan and participated (as he blames them) in Moscow apartment buildings.

12) Putin calls on and threatens to "ruthlessly eliminate the bandits every time they [Chechens) cross the Chechen administrative border."

13) Putin says terrorism bas become Russia's national problem, referring to events in Dagestan and apartment bombings.

14) Russian Interior Minister Rushailo: Bin Laden sent millions of US Dollars to Chechen warlords leading the Dagestan offensive. 
The New York Times (48 news entries)

15) Putin: "The bandits will be pursued wherever they are ...If that is at an airport, then at the airport."

16) Russian police: "The terrorist attacks were carried out by Chechen fighters." [referring to Moscow bombings].

17) Russian Defense Ministry: "The remains of bandit units are trying to flee the region in small isolated groups." [referring to Chechen withdrawal from Dagestan].

18) Russian police, parliament, and Prime Minister (Putin), all point to Chechens as the culprits of terrorist attacks across Russia.

19) Putin (about Chechen incursion in Dagestan): aggression against Russia.

South Ossetia/Abkhazia-August 8, 2008-September 8, 2008.

Russian actions in Georgia's breakaway regions portrayed in positive light by the Russian regime:

RIA Novosti (23 news entries)

1) Medvedev instructs Russian armed forces to "ensure Abkhazia's and South Ossetia's security."

2) Putin: "Right [justice] is on our side" during the crisis in Georgia.

3) Putin: "We are behaving in an absolutely moral way and in the framework of all existing international laws."

4) Official Moscow says recognizing Abkhazia and South Ossetia "was needed to protect the regions following Georgia's military offensive..."

5) Medvedev: Russia is "a guarantor of security in the Caucasus."

6) Medvedev: "As president, I am obliged to protect the lives of our citizens wherever they may be. We will not let those guilty of killing our nationals evade punishment."

7) Official Moscow: recognizing the separatist enclaves "was needed to protect the region following Georgia's military offensive..."

8) Official Moscow called its military operation in Georgia "to force Georgia to peace."

9) Russian lawmakers: Russia must interfere in the conflict [in South Ossetia] to stop violence and ensure peace in the region. Russia would [should] protect its citizens in South Ossetia.

10) Medvedev regrets that European Union does not full understanding of "Russia's actions to repel Georgian aggression."

11) Medvedev calls Russian invasion of Georgia "the operation to force Georgian authorities to peace."

12) Medvedev: Russia acted "to ensure Abkhazia's and South Ossetia's security."

13) Medvedev: Russian mission in South Ossetia [is] to protect the lives of our citizens.

The New York Times (36 entries)

14) Medvedev: Russia's forces "completed a significant part of the operations to oblige Georgia, the Georgian authorities, to restore peace to South Ossetia." 
Georgian actions in the breakaway regions portrayed in negative light by the Russian regime:

\section{RIA Novosti (23 entries)}

1) Medvedev: "Georgian troops...staged an act of aggression against Russian peacekeepers and civilians in South Ossetia."

2) Putin underlines that Georgia attacked South Ossetia.

3) Putin: "aggressive actions of the Georgian leadership [in South Ossetia]."

4) Putin: "Georgia's attack on...South Ossetia inflicted material damages of more than $\$ 1$ billion."

5) Putin: he emphasizes that Georgia committed an act of aggression and caused extensive material damage.

6) Russian General Prosecutor's Office: Russian investigators opened a criminal case on charges of genocide in connection with events in South Ossetia.

7) Putin: he warned Georgia that its aggression against its breakaway region will provoke response.

8) Russian lawmakers: urge Russian military action against Tbilisi to respond to "Georgia's aggression."

9) Official Moscow: Georgia's attack.

10) Putin calls President Saakashvili's government "a regime of personal power (thus undemocratic regime)."

11) Putin names Ossetians as "victims of [Georgian] aggression."

12) Medvedev says that "the aggressor was punished," emphasizing that Russian military action achieved the goal of punishing aggressor.

13) During the conflict Putin at least on three occasions stated that US supported and encouraged Georgian aggression and accused it of distorting a real picture by portraying victims (Ossetians) as aggressors and aggressors (Georgians) as victims.

14) Putin said US provoked and encouraged Georgian aggression in South Ossetia to help "one of the two presidential candidates" (thus John McCain).

\section{The New York Times (36 entries)}

15) Putin: Georgians committed war crimes.

16) Foreign Minister Lavrov: Georgian attacks on what he called 'Russian citizens" in South Ossetia "amounted to ethnic cleansing."

17) Lavrov blames the West (referring to the US) for providing military assistance to Saakashvili's regime, thus accusing US of provoking war in South Ossetia. 